\title{
Effectiveness of Mahkota Dewa Fruit Extract ((Phaleria Macrocarpa (Scheff.) Boerl)) With Various Concentration of Methanol Solutions on Aedes Aegypti Larva Mortality
}

\author{
Farindira Vesti Rahmasari, Aferita Sari \\ Departement of Parasitology, Faculty of Medicine and Health Sciences \\ Universitas Muhammadiyah Yogyakarta \\ Yogyakarta-Indonesia \\ *farindira.vesti@gmail.com
}

\begin{abstract}
Dengue Hemorrhagic Fever (DHF) is a disease that is commonly found in Indonesia.The method to control Aedes aegypti is mostly done by using a chemical insecticide, despite its have some side effects. Recent studies have shown that larvacides from plant extracts are safe for the environment. This research's aims are to know the effectiveness of $L C_{50}, L C_{90}, L T_{50}$, and $L T_{90}$ Mahkota Dewa fruit extract as an Aedes aegypti larvicide. Method: This was an experimental study with post-test-onlycontrol-group design, consist of 9 treatment groups (concentration $0.125 \%, 0.25 \%, 0.5 \%, 0.75 \%, 1 \%, 5 \%, 2 \%, 2.5 \%$, $3 \%$ ) and 2 control groups (positive and negative). The result was analyzed by using Shapiro-Wilk test, Kruskal Wallis test, Mann Whitney test and Probit test. Results: The result on Kruskal Wallis test shows Mahkota Dewa fruit extract effective on the death of Aedes aegypti larvae, Mann Whitney test showed no significant difference between positive control group with concentration $2 \%, 2.5 \%, 3 \%$ whereas between the negative control group and the treatment there were significant differences for all concentrations and in the Probit analysis are $L C_{50}=1.363 \%, L C_{90}=\mathbf{2 . 3 3 9} \%$ and $L T_{50}=1.850$ hours, , $L T_{90}=11.946$ hours. Mahkota dewa fruit extract in $3 \%, 2.5 \%$ and $2 \%$ are effective as larvacide to Aedes aegypti.
\end{abstract}

Key Words---Mahkota Dewa; Aedes aegypti; Larvicides

\section{INTRODUCTION}

Dengue Hemorrhagic Fever (DHF) is a major health problem which are consists of 4 serotypes DEN-1, DEN-2, DEN-3, DEN-4. This disease can be found in tropical and subtropical areas including Indonesia [1]. The World Health Organization (WHO) listed Indonesia as the country with the highest dengue fever case in Southeast Asia [2]. Until now there has not been found a special drug for the eradication of dengue to cure this disease. Eradication can only be done by vector control. Aedes aegypti mosquito vector control can be done by using several methods, such as environmentally, biologically, and chemically [3]. Efforts to reduce the side effects of using chemical insecticides should be sought as a safer alternative. Recent studies have shown that larvacids derived from plant extracts are safe for the environment, degradable, and specific to the target [4]. This effort is expected to inhibit the life cycle of Aedes aegypti mosquitoes so they can not develop into adulthood. The content of active compounds from the mahkota dewa fruit extract has been widely used for various diseases. Because of the active ingredients that probably can act as larvicidal, low cost and easily obtainable, the researchers chose the mahkota dewa to be used in this research. This research is necessary to see whether the extract of ((Phaleria macrocarpa (Scheff.) Boerl)) is effective as Aedes aegypti larvicidal.

\section{MATERIAL AND METHOD}

This research uses pure experiment with post test only control group design method. In this way it is possible to measure the effect of treatment (intervention) on one experimental group by comparing with other experimental groups and control groups. There are 9 treatment groups (with concentration $0.125 \%, 0.25 \%, 0.5 \%, 0.75 \%, 1 \%, 5 \%, 2 \%$, $2.5 \%$, and $3 \%$ ) mahkota dewa fruit extract (Phaleria macrocarpa (Scheff.) Boerl) and 2 control groups ( positive control group is contain $1 \mathrm{ppm}$ temephos solution and negative control group is contain biological water). In each sample 3 replications were performed and contain 20 Aedes aegypti larvae.

\section{RESULT}

The larvae were observed every 4 hours for 24 hours to determine the percentage of Aedes aegypti as the treatment group, temephos $1 \mathrm{ppm}$ as positive control, and biological water as negative control. 
TABLE 1. DEATHS PERCENTAGE AVERAGE IN AEDES AEGYPTI LARVAE EVERY 4 HOURS FOR 24 HOURS

\begin{tabular}{|c|l|c|c|c|c|c|c|}
\hline \multirow{2}{*}{ NO. } & \multirow{2}{*}{ GROUP } & \multicolumn{7}{|c|}{ MORTALITY (\%) } \\
\cline { 3 - 8 } & & $\mathbf{4}$ hours & $\mathbf{8}$ hours & $\mathbf{1 2}$ hours & $\mathbf{1 6}$ hours & $\mathbf{2 0}$ hours & $\mathbf{2 4}$ hours \\
\hline 1. & P1 (3\%) & 98,33 & 100 & 100 & 100 & 100 & 100 \\
\hline 2. & P2 (2,5\%) & 90 & 98,33 & 100 & 100 & 100 & 100 \\
\hline 3. & P3 (2\%) & 78,33 & 90 & 96,67 & 98,33 & 100 & 100 \\
\hline 4. & P4 (1,5\%) & 56,67 & 73,33 & 88,33 & 93,33 & 96,67 & 98,33 \\
\hline 5. & P5 (1\%) & 40 & 60 & 71,67 & 78,33 & 83,33 & 91,67 \\
\hline 6. & P6 (0,75\%) & 30 & 45 & 61,67 & 71,67 & 76,67 & 80 \\
\hline 7. & P7 (0,5\%) & 16,67 & 28,33 & 40 & 55 & 63,33 & 66,67 \\
\hline 8. & P8 (0,25\%) & 0 & 5 & 15 & 31,67 & 38,33 & 43,33 \\
\hline 9 & P9 (0,125\%) & 0 & 1,67 & 3,33 & 6,67 & 11,67 & 15 \\
\hline 10. & K (+) Temephos & 88,33 & 100 & 100 & 100 & 100 & 100 \\
\hline 11. & K (-) Air biologis & 0 & 0 & 0 & 0 & 0 & 0 \\
\hline
\end{tabular}

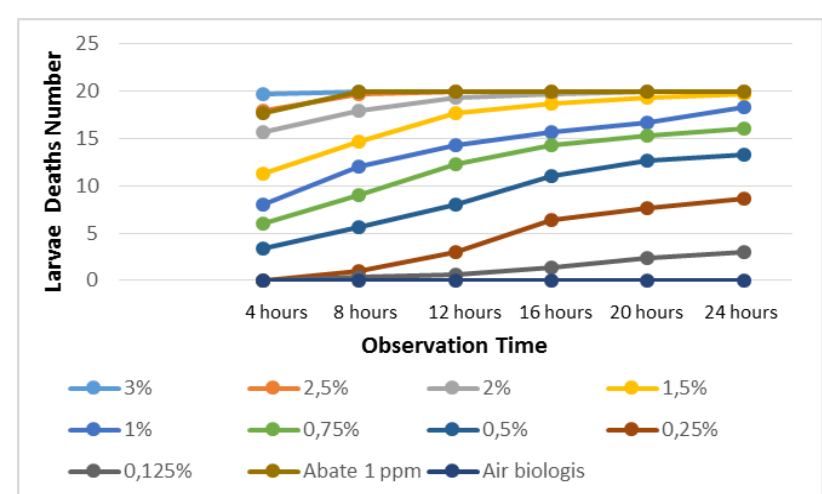

Fig. 1. Comparison Number of Aedes aegypti larvae Deaths Observation Every 4 Hours For 24 Hours.

\section{DISCUSSION}

Table 1 and Fig. 1 shows Aedes aegypti larvae deaths were observed in the treatment group and positive control group, while in the negative control group there were no Aedes aegypti larvae deaths. In the treatment group showed higher larvae mortality rate with increasing concentration and length of exposure time. The statement was correlates with other study [5], which states test larvae deaths in each group shows the deaths number is increase with the duration of exposure, supported also by other research [6] which states that the higher concentration of extract correlates with the higher larvae deaths percentage.

Based on Kruskal-Wallis test results shows a significant difference from each treatment group with $\mathrm{p}=$ 0,000 . It proves that the mahkota dewa fruit extract (Phaleria macrocarpa (Scheff.) Boerl) with methanol solvent is effective as Aedes aegypti larvicide. This statement is supported by Research in 2014 [5], that the mahkota dewa fruit extract is effective as Aedes aegypti larvicide. The death of Aedes aegypti larvae caused by this extract can be due to the content of toxic substances that can enter in the larvae body and cause death, the solvent is used to bind the substance needed to kill the larvae. The absence of food sources during the trial cause larvae have only one source of food that is saponin which
TABLE 2. PROBIT $L C_{50}$ DAN $L C_{90}$ RESULTS

\begin{tabular}{cccc}
\hline $\mathrm{M}$ & $L C_{x}$ & \multicolumn{2}{c}{ Border Range } \\
\cline { 3 - 4 }$(\%)$ & & Bottom & Upper \\
\hline 10 & 0,387 & 0,031 & 0,656 \\
\hline 25 & 0,849 & 0,568 & 1,072 \\
\hline $\mathbf{5 0}$ & $\mathbf{1 , 3 6 3}$ & 1,148 & 1,550 \\
\hline $\mathbf{9 0}$ & $\mathbf{2 , 3 3 9}$ & 2,152 & 2,556 \\
\hline 95 & 2,616 & 2,412 & 2,865 \\
\hline
\end{tabular}

enter into larvae body through mouth and resulted in surface tension Tractus digestivus larva mucous membrane decrease so that tract wall become corrosive. This condition makes the larvae body is weak and eventually die.

From the result of post hock-mann whitney test, it can be concluded that 3\%, 2.5\%, and 2\% efficacy concentration of (Phaleria macrocarpa (Scheff.) Boerl) in killing Aedes aegypti larvae is similiar to positive control group. Concentrations ranging from $2 \%$ were able to kill Aedes aegypti larvae by $100 \%$ within 24 hours. Likewise with other research at $2 \%$ concentration is able to kill $100 \%$ larvae within 24 hours [5]. According to research [7] on the mahkota dewa fruit are consist of different compounds which are flavonoids, saponins and alkaloids [8]. Flavonoids have a way to enter the larvae body through the respiratory system which will then cause wilting nerves and respiratory system damage. It can cause larvae does not breathe and eventually die [9].

In the comparison in post hock-mann whitney test, there was significant difference between treatment group and negative control $(p<0,05)$. From the results can be concluded that concentration of mahkota dewa fruit extract $3 \%, 2.5 \%$, $2 \% 1.5 \%, 1 \%, 0.75 \%, 0.5 \%, 0.25 \%$, and $0.125 \%$ have the effectiveness of killing the larvae which is not the same as the negative control that does not cause death to the larvae. So all 
of concentration extract has the ability to kill Aedes aegypti larvae.

The statement is supported by research in 2013 [6] which states that there is significant difference between treatment groups $2.5 \%, 2 \%$, and $1.5 \%(\mathrm{p}=<0.05)$, so it can be said that mahkota dewa fruit extract $2,5 \%$ and $2 \%$ has higher potency than $1.5 \%$. This is contrast to other research [5] in the comparison between the positive control group and the concentration group of $0.25 \%, 0.75 \%$ and $1 \%$ obtained $\mathrm{p}=$ $<0.05$ (there are significant differences), while the $0.5 \%$ concentration was found to be no significant difference ( $\mathrm{p}=>$ 0.05 ). So it can be concluded that $0.5 \%$ concentration has similar larvacidal potency as positive control and according to statistic value this concentration is the optimal and most effective concentration as larvacidal compared with concentration which is higher $0.75 \%$ and $1 \%$.

This study shows an increase in the number of deaths of test larvae due to increased exposure time. The duration of exposure will affect the amount of mahkota dewa fruit extract that enter the body of the test larvae. It will increase the effectiveness of the extract, making Aedes aegypti larvae become weaker and eventually die. The higher concentration that enter larvae body, it will increase the amount of toxin substances contained in the extract, so the number of test larvae death will increase. From other research [10]. Alkaloids in insects act as a stomach poison. Alkaloids can degrade cell membranes to enter and damage cells. In addition, alkaloids also work by disrupting the larva nervous system and inhibiting the action of acetylcholinesterase enzymes.The statement was supported by other research [8] in 2008 which stated that the efficacy of insecticides for killing insects is very dependent on the shape, the way substances enter the insect body, kinds of chemicals, concentration, and amount (dose) insecticide. Research conducted earlier in 2013 [6] from concentrations $2.5 \%, 2 \%, 1.5 \%, 1 \%, 0.5 \%, 0.25 \%$ and $1.25 \%$ respectively. The value $L C_{50}$ and $L C_{90} 1.175 \%$ dan $1.840 \%$, and $L T_{50}$ and $L T_{90}$ are 0.811 hours and 11.879 hours. While in this study according to Table 2 and Table 3 obtained $L C_{50}$ and $L C_{90}$ values are $1.363 \%$ and $2.339 \%$, while $L T_{50}$ and $L T_{90}$ value are 1.850 hours and 11.946 hours. Thus, when compared, the effectiveness of Mahkota Dewa fruit extract (Phaleria macrocarpa (Scheff.) Boerl) as Aedes aegypti larvicide with ethanol solvent is more effective than the effectiveness of mahkota dewa fruit extract (Phaleria macrocarpa (Scheff.) Boerl) with methanol solvent. This result can be due to many factors including; the amount of flavonoids, saponins, and alkaloid contained in extract or methanol solvent is less able to bind toxin substances which is needed in killing the larvae than ethanol solvent.

\section{CONCLUSION}

The treatment group at concentrations of $3 \%, 2.5 \%, 2 \%$ had the same effectiveness compare to positive control group temephos $1 \mathrm{ppm}$. The higher concentration of Mahkota Dewa fruit extract (Phaleria macrocarpa (Scheff.) Boerl) correlated with the stronger ability in killing Aedes aegypti larvae.

\section{ACKNOWLEDGMENT}

We acknowledge to LP3M UMY that funded this research. Also thank you to Department Parasitology Faculty of Medicine and Health Sciences who helped us in laboratory process.

\section{REFERENCES}

[1] Centre of Disease Control, Dengue Fever, 2004. http://www.cdc.gov/ncidod/dvbid/dengue/index.htm

[2] Ditjen PP \& PL DepKes RI, Demam Berdarah Dengue. Buletin Jendela Epidemiologi. Pusat Data dan Surveilans Epidemiologi Kementrian Kesehatan RI, Jakarta, 2009.

[3] Chahaya, I. Pemberantasan Vektor Demam Berdarah Di Indonesia. 2011. http://repository.usu.ac.id/bitstream/123456789/3715/1/fkm

[4] Kihampa C, C.C. Joseph, M.H.H kunya, S.M. Magesa, A Hassanali, and Heydenreich M, Larvicidal and IGR Activity of Extract Tanzanian. J. Vector Borne Dis. Vol 46 (2):145-52, 2009.

https://www.ncbi.nlm.nih.gov/pubmed/19502695

[5] .Nariatri, A.S. Setyaningrum, E. Saftarina, F. dan Kurniawan, B, The effectiveness test of the extract of the crown of Phaleria macrocarpa (Scheff.) Boerl. as larvicide to Aedes aegypti larvae. (Uji Efektivitas ekstrak buah mahkota dewa (Phaleria macrocarpa(Scheff.) Boerl.) sebagai larvasida terhadap larva Aedes aegypti. Medical Journal of Lampung University, 2014.

http://juke.kedokteran.unila.ac.id/index.php/majority/article/view/169

[6] Nugroho, T.F., The effectiveness of the crown leaf extract of Phaleria macrocarpa (Scheff.) Boerl. As a larvacid Aedes aegypti (Efektivitas ekstrak daun mahkota dewa (Phaleria macrocarpa (Scheff.) Boerl.) sebagai larvasida Aedes aegypti). 2013.

http://journal.umy.ac.id/index.php/mm/article/view/1063

[7] Arjadi, F., Regeneration of Langerhans Cells in White Rats (Rattusnorvegicus) Diabetes Raised with Flesh of Divine Crown Fruit (Phaleria macrocarpa (Scheff.) Boerl). (Regenerasi Sel Pulau Langerhans Pada Tikus Putih (Rattusnorvegicus) Diabetes Yang Diberi Rebusan Daging Buah Mahkota Dewa (Phaleria macrocarpa (Scheff.) Boerl)). Sains Medika Journal of Medicine and Health, Vol. 2, No.2, Juli-Desember

2010 http://www.sainsmedika.fkunissula.ac.id/index.php/sainsmedika/article /view/28

[8] Hoedojo R, Zulhasril., Insecticides and resistance: medical parasitology (Insektisida dan resistensi: parasitologi kedokteran). Edisi IV.Jakarta : Fakultas Kedokteran Universitas Indonesia. Depok, 2008.

[9] Robinson, T., Organic Content of High Plants (Kandungan Organic Tumbuhan Tinggi. Edisi Keempat). Terjemahan Kosasih Padmawinata. ITB Press. Bandung, 1995.

[10] Cania, E. Effectiveness Test of Legundi Leaf Extract (Vitex trifolia) as Larvasida to Instar larvae III Aedes aegypt (Uji Efektivitas Ekstrak Daun Legundi (Vitex trifolia) sebagai Larvasida terhadap Larva Instar III Aedes aegypti). Skripsi. Fakultas Kedokteran Universitas Lampung, Lampung, 2012. 